\section{Great American Smokeout - November 15, 2018}

The American Cancer Society's 43rd annual Great American Smokeout will be held on November 15, 2018. The Great American Smokeout is an annual event that encourages smokers to make a plan to quit smoking (https://www.cancer.org/healthy/stay-away-from-tobacco/ great-american-smokeout.html).

A report in this issue of MMWR ( 1 ) indicates that in $2017,14.0 \%$ of U.S. adults were current cigarette smokers, the lowest prevalence recorded since monitoring began in 1965 . Nonetheless, smoking remains the leading preventable cause of disease, disability, and death in the United States (2). Each year, an estimated 480,000 U.S. adults die from cigarette smoking and secondhand smoke exposure (2).

Smokers can and do quit smoking: former smokers now outnumber current smokers (2). Among current U.S. adult smokers, nearly two out of three want to quit smoking, and approximately half made a quit attempt in the preceding year (2). Getting effective help through counseling and use of medications can increase the chances of quitting by as much as threefold (3).

Information and support for quitting smoking is available at 800-QUIT-NOW (800-784-8669). CDC's Tips From Former Smokers campaign offers additional resources (https://www.cdc.gov/tips).

\section{References}

1. Wang TW, Asman K, Gentzke AS, et al. Tobacco product use among adults-United States, 2017. MMWR Morb Mortal Wkly Rep 2018;67:1225-32.

2. US Department of Health and Human Services. The health consequences of smoking - 50 years of progress: a report of the Surgeon General. Atlanta, GA: US Department of Health and Human Services, CDC; 2014.

3. Fiore MC, Jaen CR, Baker TB, et al. Treating tobacco use and dependence: 2008 update. Clinical practice guideline. Respir Care 2008;53:1217-22.

\section{Tobacco Product Use Among Adults - United States, 2017}

Teresa W. Wang, $\mathrm{PhD}^{1}$; Kat Asman, $\mathrm{MSPH}^{1}$; Andrea S. Gentzke, $\mathrm{PhD}^{1}$; Karen A. Cullen, $\mathrm{PhD}^{2}$; Enver Holder-Hayes, $\mathrm{MPH}^{2}$; Carolyn Reyes-Guzman, $\mathrm{PhD}^{3}$; Ahmed Jamal, MBBS ${ }^{1}$; Linda Neff, $\mathrm{PhD}^{1}$; Brian A. King, $\mathrm{PhD}^{1}$

Cigarette smoking harms nearly every organ of the body and causes adverse health consequences, including heart disease, stroke, and multiple types of cancer (1). Although cigarette smoking among U.S. adults has declined considerably, tobacco products have evolved in recent years to include various combustible, noncombustible, and electronic products $(1,2)$. To assess recent national estimates of tobacco product use among U.S. adults aged $\geq 18$ years, CDC, the Food and Drug Administration (FDA), and the National Institutes of Health's National Cancer Institute analyzed data from the 2017 National Health Interview Survey (NHIS). In 2017, an

\section{INSIDE}

1233 Firearm Homicides and Suicides in Major Metropolitan Areas — United States, 2012-2013 and 2015-2016

1238 Prevalence of Arthritis Among Adults with Prediabetes and Arthritis-Specific Barriers to Important Interventions for Prediabetes - United States, 2009-2016

1242 Progress Toward Poliomyelitis Eradication Pakistan, January 2017-September 2018

1246 Notes from the Field: Increase in Coccidioidomycosis - Arizona, October 2017-March 2018

1248 Notes from the Field: Cronobacter sakazakii Meningitis in a Full-Term Neonate Fed Exclusively with Breast Milk — Indiana, 2018

1251 QuickStats

Continuing Education examination available at https://www.cdc.gov/mmwr/cme/conted_info.html\#weekly.

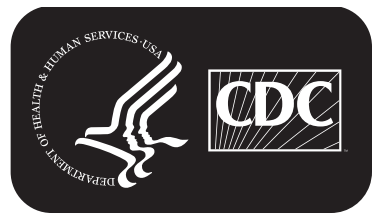

U.S. Department of Health and Human Services Centers for Disease Control and Prevention 